\title{
Interactive comment on "Global maps of Forel-Ule index, hue angle and Secchi disk depth derived from twenty-one years of monthly ESA-OC-CCI data" by Jaime Pitarch et al.
}

Jaime Pitarch et al.

jaime.pitarchportero@artov.ismar.cnr.it

Received and published: 8 January 2021

See attached.

Please also note the supplement to this comment:

https://essd.copernicus.org/preprints/essd-2020-316/essd-2020-316-AC1-

supplement.pdf 